\title{
Caloric Density of Aquatic Macrophytes in Different Environments of the Baía River Subsystem, Upper Paraná River Floodplain, Brazil
}

\author{
Célia de Almeida Lopes $^{1 *}$, Anna Christina Esper Amaro de Faria ${ }^{1}$, Gislaine Iachstel \\ Manetta $^{1}$ and Evanilde Benedito-Cecilio ${ }^{2}$ \\ ${ }^{1}$ Programa de Pós-Graduação em Ecologia de Ambientes Aquáticos Continentais; celiaalmeidalopes@hotmail.com. \\ ${ }^{2}$ Departamento de Biologia, Núcleo de Pesquisas em Limnologia Ictiologia e Aqüicultura - NUPÉLIA; \\ Universidade Estadual de Maringá; Av. Colombo, 5790; 87020-900; Maringá - PR - Brasil
}

\begin{abstract}
The aim of this work was to determine the caloric density of leaves, stems and roots of aquatic macrophytes in different environments of the Baía subsystem (Baía river and Fechada and Guaraná lagoons) on the Upper Paraná river floodplain, in addition to identify the variability between ecological groups. Samplings of Eichhornia crassipes, Salvinia spp, Pistia stratiotes, Eichhornia azurea, Polygonum sp, Cyperaceae and Poaceae were carried out in February 2003. Spatial differences in the caloric densities were not observed for these plants. Caloric density values varied from $1906.9 \mathrm{cal} / \mathrm{g}$ dry weight (root) to $4675.0 \mathrm{cal} / \mathrm{g}$ dry weight (leaf). However, significant differences between the caloric content averages of the vegetative structures were observed only for Polygonum sp and Salvinia spp. In relation to the ecological groups, the highest average value was verified for the emergent macrophytes (3529.7 \pm 722.5$)$, which were significantly different from the floating ones (3056.5 \pm 571.0$)$. There was no difference between the sites included in the subsystem when the caloric densities were compared.
\end{abstract}

Key words: Paraná river, floodplain, aquatic macrophytes, calorimetry

\section{INTRODUCTION}

Tropical and subtropical floodplains possess an abundance of aquatic macrophytes of different species and ecological groups (Bini, 1996; Bini et al., 2001). The presence of these plants generally represents high primary production, biomass (Esteves, 1998; Pedralli, 2000), nutrient cycling and stock capacity for the ecosystem (Henry-Silva et al., 2001). For animals, they contribute to the feeding of herbivores and detritivores (Maine et al., 1999; Pompêo et al., 1999), in addition of serving as food substrate for algivores and invertivores (Casatti et al., 2003).
In recent years, biomass production rates and the chemical composition of aquatic macrophytes have been analyzed by various researchers (Esteves, 1982; Esteves and Thomaz, 1990; Camargo and Esteves, 1996; Henry-Silva et al., 2001). On the other hand, the accumulated energy in the plant tissues of these primary producers (made available to the system) has undergone little investigation (Golley, 1961; Thomaz and Esteves, 1984).

Differences in the caloric density between species are caused by exogenous and endogenous factors (Caspers, 1977), trophic and climatic conditions (Dykyjova and Pribil, 1975), in addition to the

\footnotetext{
${ }^{*}$ Author for correspondence
} 
physiology of each species. The average caloric value of aquatic vascular plants varies little, but there are some differences between the ages, as well as between organs of the same plant (Dykyjova and Pribil, 1975; Caspers, 1975).

As for botany, especially for superior plants, there is a distinct dependence of caloric values on climatic conditions, the availability of water and the concentration of dissolved salts in the soil (Caspers, 1975).

These differences can also depend on the ecological group (emergent, submerged and floating). Bianchini Junior (2003) affirms that each group responds to the abiotic and biotic factors in a different way, in accordance with adopted survival strategies.

In the preparation of energy flow models that explain food webs, energy data from Upper Paraná river floodplain macrophytes had not yet been obtained, considering that studies had only been made with animal groups (Benedito-Cecilio and Morimoto, 2002; Benedito-Cecilio, et al., 2004; Vismara et al., 2004). So, this work had as its aim the analysis of the caloric density of the leaves, stems and roots of aquatic macrophytes collected in the Baía river and in two lagoons of its subsystem. It was hypothesized that the caloric content of aquatic macrophytes could be associated: (1) with the plant organ (leaf, stem and root); (2) with the ecological group (emergent and floating); or (3) with the environment (lagoon with or without a link to the river).

\section{MATERIALS AND METHODS}

\section{Study Area}

This study was performed in the Baía river and in two lagoons of its environment (Fechada and Guaraná) (Fig. 1).

The Baía river (moderately lotic) presents a varied width and an average depth of $3.2 \mathrm{~m}$, with narrow stretches having high embankments and occupied by riparian vegetation or cultivated fields. In the wide stretches, the embankments are low and the vegetation consists of flooded fields (Manetta et al., 2003).

Fechada lagoon has an elongated shape, a length of $624.4 \mathrm{~m}$ and an average depth of $2.5 \mathrm{~m}$. It does not present a direct connection with the Baía river, which is $100 \mathrm{~m}$ away. The margin consists of a few trees (1\%) and high macrophyte abundance
(Manetta et al., 2003). Guaraná lagoon has a rounded shape, a length of $386.5 \mathrm{~m}$ and an average depth of $2.1 \mathrm{~m}$. It presents a macrophyte-laden connection with the Baía river that is $70 \mathrm{~m}$ long and $18 \mathrm{~m}$ wide. The marginal embankment presents a height of $0.4 \mathrm{~m}$ and its margins are laden with grasses (95\%) and bushes (5\%) (Manetta et al., 2003).

\section{Methodology}

Samplings were obtained in February 2003. The aquatic macrophytes were collected for caloric analysis of the leaf, stem and root, and divided into emergent (Cyperaceae, Poaceae, Eichhornia azurea (Sw.) Kunth and Polygonum sp.) and floating (Eichhornia crassipes (Mart) Solm., Salvinia spp and Pistia stratiotes (L.)) ecological groups.

Different aquatic macrophyte individuals $(\mathrm{n}=5)$ belonging to the same family and species were randomly sampled. The plants were put in plastic bags and labeled with the site name and collection date. Later, the samples were washed in running distilled water, and the vegetative organs (leaf, stem and root) separated and dried in a greenhouse at $60^{\circ} \mathrm{C}$. Next, they were softened in a ball mill and submitted to combustion in a Parr calorimetric bomb.

The data of temperature from water, dissolved oxygen, eletric conductivity, $\mathrm{pH}$, transparency and alkalinit were taken daily and supplied by the Limnology Laboratory.

Caloric differences were investigated using a null model ANOVA and the program ECOSIM (Gotelli and Entsminger, 2003). Graphic inspections were carried out using the program STATISTICA.

\section{RESULTS}

It was verified that the three environments studied present similarities as regards average water temperature, $\mathrm{pH}$ and transparency. The concentration of $\mathrm{O}_{2}$ was higher in the Baía river $(2.0 \mathrm{mg} / \mathrm{L})$, while the conductivity of Fechada Lagoon reached about $32 \mu \mathrm{s} / \mathrm{cm}$. Alkalinity was higher in Guaraná lagoon $(190.4 \mu \mathrm{M})$, while the lowest value was recorded in Fechada lagoon (134.5) (Table 1). 


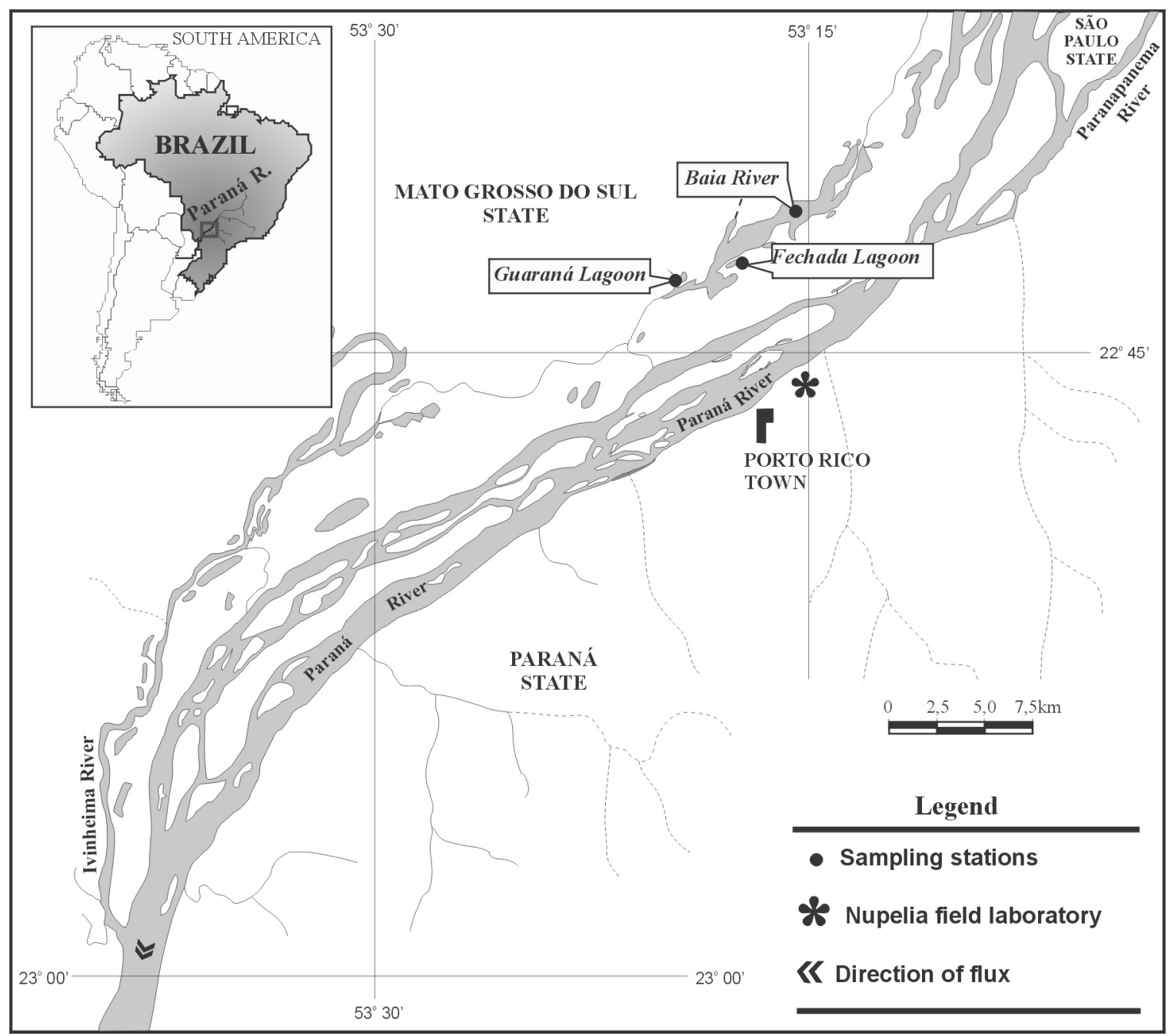

Figure 1 - Site of sampling in the Paraná river floodplain.

Table 1 - Physic and chemical variables in different environments of the Baía river.

\begin{tabular}{l|c|c|c|c|c|c}
\hline \multicolumn{1}{c|}{ Site } & $\begin{array}{c}\text { Water } \\
\text { temperature } \\
(\mathbf{0} \mathbf{C})\end{array}$ & $\begin{array}{c}\text { Dissolved } \\
\mathbf{0 x y g e n}(\mathbf{m g} / \mathbf{L})\end{array}$ & $\begin{array}{c}\text { Electric } \\
\mathbf{C o n d u c t i v i t y} \\
(\boldsymbol{\mu} \mathbf{s} / \mathbf{c m})\end{array}$ & $\mathbf{p H}$ & $\begin{array}{c}\text { Transparency } \\
(\mathbf{m})\end{array}$ & $\begin{array}{c}\text { Alkalinity } \\
(\boldsymbol{\mu} \mathbf{M})\end{array}$ \\
\hline Baía river & 29.5 & 2.07 & 23.9 & 5.61 & 0.75 & 168.8 \\
Guaraná lagoon & 29.5 & 0.56 & 26.2 & 5.40 & 0.60 & 190.4 \\
Fechada lagoon & 29.1 & 0.66 & 31.9 & 5.75 & 0.55 & 134.5 \\
\hline
\end{tabular}

Source: UEM/NUPÉLIA/PELD/CNPq (2003).

Caloric density values varied from $1906.9 \mathrm{cal} / \mathrm{g}$ dry weight (root) to $4075.5 \mathrm{cal} / \mathrm{g}$ dry weight (leaf) for Cyperaceae specimens; from $2767.4 \mathrm{cal} / \mathrm{g}$ dry weight (root) to $3316.0 \mathrm{cal} / \mathrm{g}$ dry weight (root) for E. azurea; from $2196.4 \mathrm{cal} / \mathrm{g}$ dry weight (leaf) to $3798.3 \mathrm{cal} / \mathrm{g}$ dry weight (leaf) for E. crassipes; $3114.3 \mathrm{cal} / \mathrm{g}$ dry weight (stem) to $4613.1 \mathrm{cal} / \mathrm{g}$ dry weight (leaf) for Poaceae; from 2547.7 cal/g dry weight (root) to $4675.0 \mathrm{cal} / \mathrm{g}$ dry weight (leaf) for Polygonum sp; from 2332.4 cal/g dry weight (root) to $3470.2 \mathrm{cal} / \mathrm{g}$ dry weight (root) for P. stratiotes; from $2200.8 \mathrm{cal} / \mathrm{g}$ dry weight (root) to $3933.8 \mathrm{cal} / \mathrm{g}$ dry weight (leaf) for Salvinia spp. (Fig. 2) 


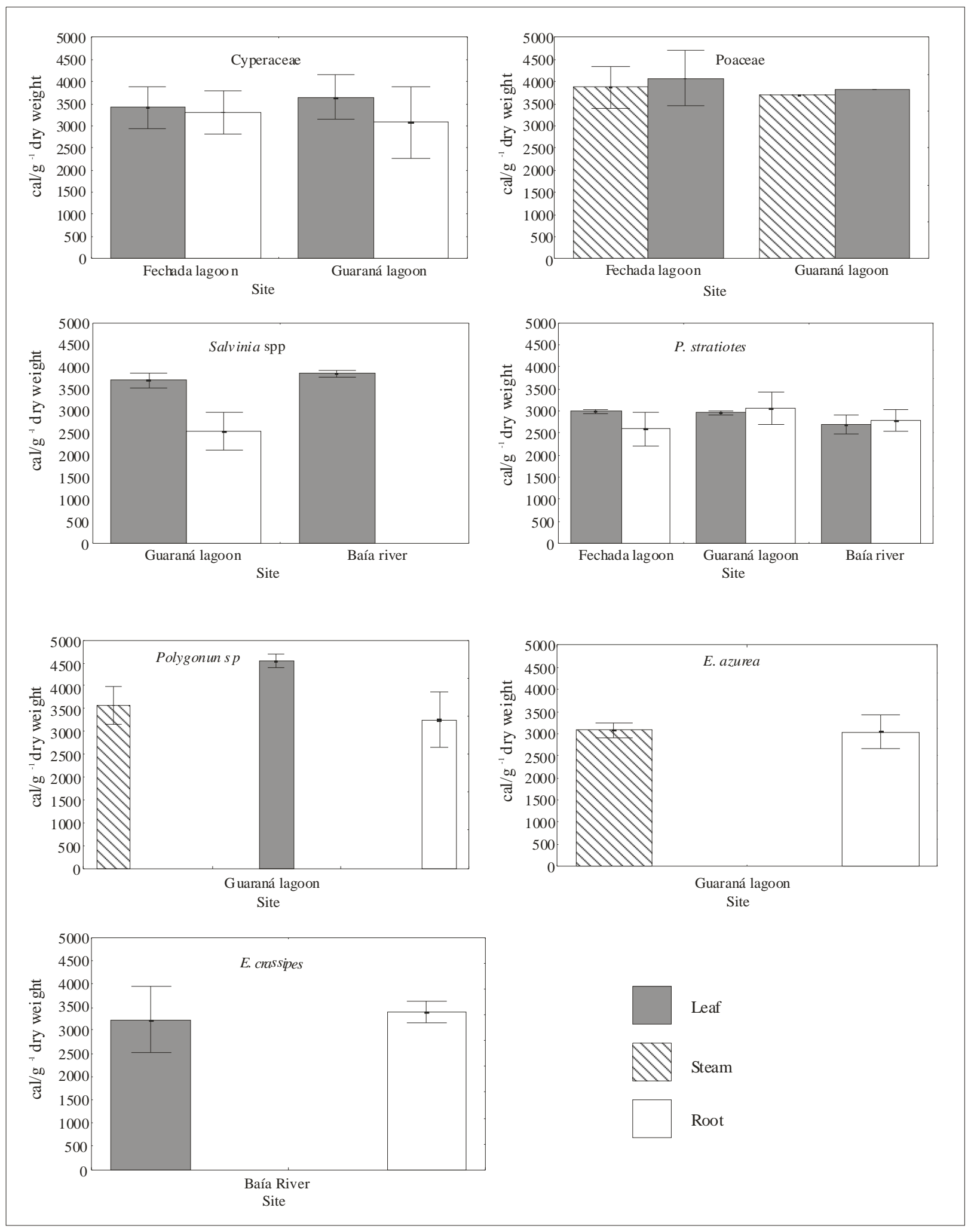

Figure 2 - Caloric density of vegetative organs of aquatic macrophytes in different environments of the Baía subsystem. 


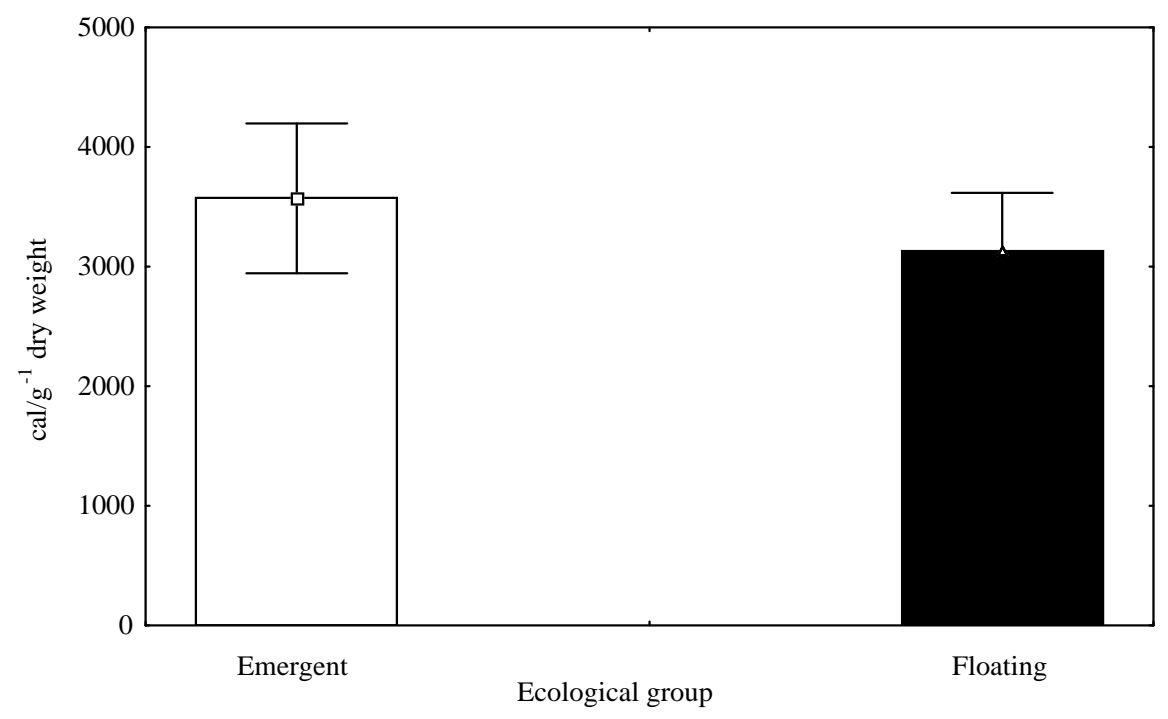

Figure 3 - Caloric density of ecological groups of analysed aquatic macrophytes.

The highest average caloric densities were observed for aquatic macrophyte leaves, with the exception of the E. crassipes specimens collected in the Baía river and the $P$. stratiotes specimens taken from Guaraná lagoon and the Baía river.

In addition, the values obtained for the roots presented the greatest variations, except for $E$. crassipes. However, significant differences between the vegetative structure averages were observed between leaves and roots from Salvinia spp. $(\mathrm{OI}=50.2, \mathrm{p}<0.05)$ while for Polygonum $\mathrm{sp}$ all the vegetable organs had different caloric values different $(\mathrm{OI}=6.97, \mathrm{p}<0.05)$. For both plants, the leaves had the highest average of caloric densities (cal/g dry weight) when compared to the roots (Polygonum sp: root $=$ 3249.28, leaf $=4540.79$; Salvinia spp: root $=$ 2535.32; leaf $=3698.01$ ).

Spatial differences in the caloric densities were not observed for the studied plants (Cyperaceae: $\mathrm{OI}=$ 0.018, $\mathrm{p}=0.90$; Poaceae: $\mathrm{OI}=0.26, \mathrm{p}=0.66 ; P$. stratiotes: $\mathrm{OI}=2.43, \mathrm{p}=0.12 ;$ Salvinia $\mathrm{spp}: \mathrm{OI}=$ $1.29, \mathrm{p}=0.20)$.

In relation to the ecological groups, the highest average value was verified for the emergent macrophytes (3529.7 \pm 722.5$)$, which were significantly different from the floating ones (3056.5 \pm 571.0$)$ (Fig. 3).

\section{DISCUSSION}

The physical and chemical variable values did not present marked differences between the analyzed environments. This similarity may be responsible for the absence of caloric variation between the macrophytes of the river, open lagoon and closed lagoon. Abiotic factors such as $\mathrm{pH}$, ionic concentration, nutrients, light, dissolved oxygen, water level and temperature (Ikusima and Gentil, 1985; Pompêo et al., 1999) and biotic factors such as herbivory, competition and parasitism (Neill, 1989; Esteves, 1998; Duarte, 1992) influence the spatial variations in the physical, chemical and biological characteristics of the macrophytes. Spatial variation was not verified inside the Baía river subsystem (main channel and lagoons). But, it is necessary to analyse this variation between other subsystems from the Paraná river floodplain because these plants also influence the dynamics of the environment, resulting in differences in their caloric values. Dourado et al. (2004) identified spatial variability for macrophytes in fluvial, transition and lacustrine zones from reservoirs. The caloric values of these plants affect the entire food chain since they represent one of the most productive communities in aquatic ecosystems (Camargo et al., 1983; 2003).

In general, the macrophytes presented the highest average values of energy in the leaves in relation to the stems and roots, except for P. stratiotes and E. crassipes. In Lobo Dam in São Paulo State, 
Esteves and Thomaz (1990) also verified this relationship for two macrophytes (Nymphoides indica (L) and Pontederia cordata (L)). These results may be due to the high content of nutrients such as soluble carbohydrates, lipids and polyphenols (Esteves and Nogueira, 1991; Esteves, 1998) and high leaf metabolism, the result of the great enzymatic activity of photosynthetically active structures (Henry-Silva and Camargo, 2002). However, for other plants this organ was not more caloric and differences were not verified. According to Sieghardt (1973), the translocation of organic compounds between vegetative organs can also cause calorimetric differences, and he also emphasizes that in temperate regions the processes of energy distribution between the plant organs are more evident than in tropical regions, mainly because of conspicuous seasonality. So this question needs more investigation in neotropical regions.

The efficiency of vegetative reproduction and high nutrient absorption (area/volume) are among the possible factors that confer high productivity on floating and emergent aquatic macrophytes in aquatic ecosystems (Esteves, 1998). Both groups possess high absorption and vegetative growth. However, differences exist in the chemical composition of these groups, since they presented different values in the energy content. These results can be related to a larger amount of cell wall fraction tissues in emerging macrophytes, which need larger sustentability. Therefore energy content increases along with a larger content of carbon, consequently, it is high among woody plants (Larcher, 2000).

Although studies have shown relevant differences between vegetative organs (Dykyjova and Pribil, 1975; Caspers, 1975), it may be inferred, based on the results obtained, that energy investigations of the Baía river subsystem may be carried out on the vegetative organs as a whole, with the exception of only Polygonum sp and Salvinia spp, in which significant differences were verified. It is worth emphasizing the possibility of investigation in one of the environments of the subsystem and/or all of them, mainly for $P$. stratiotes. However, generalizations between ecological groups should be avoided. The caloric values were not influenced by the kind of environment (with or without communication) but suffered effect from the ecological group. In this way, the first hypothesis was accepted for Polygonum sp and Salvinia spp. In relation to the second hypothesis, the specimens were rejected in the local studies and the third hypothesis was accepted and showed a difference between the ecological groups.

In addition, considering that macrophytes represent a stock of nutrients for aquatic consumers (Casatti et al., 2003) exercising a relevant role in system cycling, these results make it possible to prepare models representing the potential energy that could be transferred to upper links. However, allied to caloric density, future researches on the chemical composition and digestibility of aquatic plants are important complements because these plants can present the same caloric density, but different chemical constitutions (Esteves, 1982) and high energy values. So, it is important to note the low efficiency of using the energy due to the high cell wall fraction.

The Upper Paraná river floodplain presents high spatial heterogeneity (Thomaz et al., 1997) and, therefore, the results presented here for the Baía river may not be valid for other environments of the floodplain, for example Ivinheima and Paraná subsystems. Complementary studies about the floodplain may clarify this question, as well as the energy flow in the food chains. The acquisition of information of this nature is urged as anthropogenic impacts occur at a velocity and intensity superior to the current acquisition of ecological data, making the implementation of adequate management and conservation measures impossible.

\section{ACKNOWLEDGEMENTS}

We thank NUPELIA and Maria do Carmo Roberto for the logistical support, Elãine Christine dos Santos Dourado and Renata Pereira Pinheiro for assistance in the preparation and combustion of the samples, Kazue Kawakita Kita for the help identifying the aquatic macrophytes, and Michele de Faveri Gimenes for the collaboration in the bibliographic revision.

\section{RESUMO}

O presente trabalho teve por objetivo determinar a densidade calórica de folhas, caules e raízes de macrófitas aquáticas, em diferentes ambientes do subsistema Baía (Rio Baía e lagoas Fechada e do 
Guaraná) na planície de inundação do alto rio Paraná, além de identificar a variabilidade entre grupos ecológicos. As amostragens foram realizadas em fevereiro de 2003, sendo coletadas amostras de diferentes macrófitas, Eichhornia crassipes, Salvinia spp, Pistia stratiotes, Eichhornia azurea, Polygonum sp, Cyperaceae e Poaceae. Diferenças espaciais nas densidades calóricas não foram observadas para as plantas estudadas. Os valores de densidade calórica variaram de 1906,9 cal/g de peso seco (raiz) a $4675,0 \mathrm{cal} / \mathrm{g}$ de peso seco (folha). Entretanto, diferenças significativas entre as médias dos conteúdos calóricos das estruturas vegetativas foram observadas somente para Polygonum sp e Salvinia spp. Em relação aos grupos ecológicos, o maior valor médio foi verificado para as macrófitas emergentes $(3529,7 \pm 722,5)$ as quais foram significativamente diferentes das flutuantes $(3056,5 \pm 571,0)$. Considerando que não houve diferença entre os ambientes, conclui-se que os fatores inerentes aos ambientes analisados não foram preponderantes na determinação da densidade calórica.

\section{REFERENCES}

Benedito-Cecilio, E.; Dourado, E. C. S.; Lopes, C.A., Faria, A. C. E. A.; Pinheiro, R. P.; Bonicci, P.; Pereira, A. L. and Morimoto, M. (2004), Estimation of the energy of producers and consumers in the upper Paraná river floodplain. In: Agostinho, A. A.; Rodrigues; L.; Gomes; L. C.; Thomaz; S. M. and Miranda, L. E. The upper Paraná river floodplain long term ecological reserarch. Maringá: EDUEM. pp. 145-149.

Bianchini Jr., I. (2003), Modelos de crescimento e decomposição de macrófitas aquáticas. In: Thomaz, S. M. and Bini, L. M. Ecologia e manejo de macrófitas aquáticas. Maringá: EDUEM. pp. 85-126.

Bini, L. M. (1996), Influência do pulso de inundação nos valores de fitomassa de três espécies de macrófitas aquáticas na planície de inundação de inundação do alto rio Paraná. Arq. Biol. Tecnol., 39: (3), 715-721.

Bini, L. M.; Thomaz, S. M. and Souza, D. C. (2001), Species richeness and B-diversity of aquatic macrophtes in the Upper Paraná floodplain. Archiv fur Hydrobiologie, Stuttgart., 151: (3), 511-525.
Camargo A. F. M.; Ishii, I. H. and Esteves, F. A. (1983), Liberação de compostos orgânicos e inorgânicos para a coluna d'água durante o processo de decomposição de macrófitas aquáticas tropicais. In: Seminário Regional de Ecologia, 1985, São Carlos. Anais ... São Carlos: UFSCAR. pp. 87-99.

Camargo, A. F. M. and Esteves, F. (1996), A Influence of water level variation on biomass and chemical composition of the aquatic macrophyte Eichhornia azurea (Kunth) in a oxbow lake of the Rio MogiGuaçu (São Paulo, Brazil), Arch. Hydrobiol., 135: (3), 423-432.

Camargo, A. F. M.; Pezzato, M. M. and Henry-Silva, G. G. (2003), Fatores limitantes à produção primária de macrófitas aquáticas In: Thomaz, S. M. and Bini, L. M. Ecologia e manejo de macrófitas aquáticas. Maringá: EDUEM. pp. 59-83.

Casatti, L.; Mendes, H. F. and Ferreira, K. M. (2003), Aquatic macrophytes as feeding site for small fishes in the Rosana Reservoir, Paranapanema river, southeastern Brazil. Braz. J. Biol., 63: (2), 213-222.

Caspers, N. (1975), Kalorische Untersuchungen an der Ufervegetation cines Weihers. Oecologia, 19, 171-175.

Caspers, N. (1977), Seasonal variations of caloric values in herbaceous plants. Oecologia, 26, 379-383.

Dourado, E. C. S.; Peretti, D. and Benedito-Cecilio, E. (2004), Variability in the caloric content of vasculat plants in two Paraná State reservois. Acta Scientiarum, 26: (2), 137-142.

Duarte, C. M. (1992), Nutrient concentration of aquatic plants: Patterns across species. Limnol. Oceonogr., 77, 882-889.

Dykyjová, D. and Pribil, S. (1975), Energy content in the biomass of emergent macrophytes and their ecological efficiency. Arch. Hydrobiol., 15, 90-108.

Esteves, F. A. (1982), Biomass and analysis of the major inorganic components of floating aquatic macrophyte Eichhornia crassipes (Mart.) Solms in six reservoirs of São Paulo state (Brazil), Cienc. Cult., 34: (9), 1196-1200.

Esteves, F. A. (1998), Comunidade de macrófitas aquáticas. In: Esteves, F. A. (Ed.). Fundamentos de Limnologia. Rio de Janeiro: Interciência-FINEP. pp. 316-373.

Esteves, F. A. and Nogueira, F. (1991), Principais componentes químicos e conteúdo energético da macrófita aquática Nymphea ampla D. C., em função de seu estado fenológico. Cienc. Cult., 42: (12), 1187-1191.

Esteves, F. A. and Thomaz, S. M. (1990), Temporal variation of energy of two species of tropical aquatic macrophytes. Rev. Brasil. Biol., 50: (4), 957-962.

Golley, F. B. (1961), Energy values of ecological materials. Ecology, 42: (3), 581-584. .

Gotelli, N. J. and Entsminger, G. L. (2003), EcoSim: Null models software for ecology. Available at: http://homepages.together.net/ gentsmin/ecosim.htm. 
Henry-Silva, G. G. et al. (2001), Chemical composition from lotic ecosystems of the southern coast of the state of São Paulo (Brazil), Acta Limnologica Brasiliensia., 13: (2), 11-17. .

Henry-Silva, G. G. and Camargo, A. F. M., (2002), Valor nutritivo de macrófitas aquáticas flutuantes (Eichhornia crassipes, Pistia stratiotes e Salvinia molesta) utilizadas no tratamento de efluentes de aquiicultura. Acta Scientiarum, 24: (2), 519-526.

Ikusima, I. and Gentil, J. G. (1985), Macrophytes and its environments in four lakes in Rio Doce valley. In: Saijo. Y. and Tundisi, J. G. Limnological studies in cental Brazil, Rio Doce valey lakes and Pantanal wetland. Walter Research Institute. Nagoya University. pp. 113-125. Available at: http://www. peld.uem.br/relat2000/apresent2000.

Larcher, W. (2000), O balanço de carbono nas plantas. In: Ecofisiologia vegetal. São Carlos: Rima. pp. 69-182.

Manetta, G. I.; Benedito-Cecilio, E. and Martinelli, L. (2003), Carbon Sources and Trophic position of the main species of fishes of Baia River, Paraná River Floodplain, Brazil. Braz. J. Biol., 63: (2), 283-290.

Maine, M. A.; Suñe, N. L.; Panigatti, M. C.; Pizarro, M. J. and Emiliani, F. (1999), Relationships between water chemistry and macrophyte chemistry in lotic and lentic environments. Arch. Hydrobol., 145, 129-145.

Neill, C. (1989), Effects of nutrients and water levels on species composition in prairie whitetop (Scolochloa festucacea) marshes. Can. J. Bot., 68, 1015-1020.

Pedralli, G. (2000), Padrões florísticos como subsídios a conservação da biodiversidade de macrófitas aquáticas. In: Cavalcanti, T. B. and Walter, B. M. T. Tópicos atuais em Botânica. Brasília: Embrapa Recursos Genéticos e Biotecnologia. pp. 335- 339.

Pompêo, M. L. M.; Henry, R. and Moschini-Carlos, V. (1999), Chemical composition of tropical macrophyte Echinocloa polystachya (H.B.K.) Hitchcock in Jurimirim reservoir (São Paulo, Brazil), Hydrobiologia, 411, 1-11.

Sieghardt, H. (1973), Utilization of solar energy content of different organs of Phragmites comunnis. Trin. Plo. Arch. Hydrobiol., 20, 151-156.

Thomaz, S. M. and Esteves, F. A. (1984), Estudo da biomassa de algumas espécies de macrófitas aquáticas tropicais quanto ao seu valor nutritivo. In: Seminário Regional de Ecologia, São Carlos. Anais ... São Carlos: UFSCAR. pp. 439-467.
Thomaz, S. M.; Roberto, M. C. and Bini, L. M. (1997), Caracterização limnológica dos ambientes aquáticos e influência dos níveis fluviométricos. In: Vazzoler, A. E. A.; Agostinho, A. A.; Hahn, N. S. A planície de inundação do alto rio Paraná: aspectos físicos, biológicos e sócio-econômicos. Maringá: EDUEM. pp. 73-102.

UEM. Nupélia/PELD/CNPq. (2003), A planície alagável do alto rio Paraná: estrutura e processos ambientais - Relatório técnico. Maringá, 2001. pp. 1. (Relatório técnico - Apoio ILTER/Cnpq).

Vismara, M. R.; Benedito-Cecilio, E. and Faria, A. C. E. A. (2004), Efeito da maturação gonadal sobre o conteúdo calórico e condição geral de peixes da Planície de Inundação do alto rio Paraná. Acta Scientiarum, 26: (2), 189-199.

Received: May 11, 2004; Revised: January 13, 2005; Accepted: July 20, 2006. 